\title{
Flood control and small-scale reservoirs
}

\author{
H. Gotoh ${ }^{1}$, Y. Maeno ${ }^{1}$, M. Takezawa ${ }^{1} \&$ M. Ohnishi ${ }^{2}$ \\ ${ }^{I}$ Nihon University, Tokyo, Japan \\ ${ }^{2}$ Funabashi City Municipal Office, Funabashi, Chiba, Japan
}

\begin{abstract}
Flood control defenses such as levees, dams, reservoirs, and weirs are used to prevent rivers from bursting their banks. Among these defenses, the construction of large-scale dams has recently become an important topic of discussion in countries around the world. It is important to construct large dams to secure water for drinking, irrigation, electricity, and industrial use. However, leaders and well-informed persons in many fields have argued that the development of large-scale dams destroys the natural environment, forces residents of entire villages to leave their homes, and consumes too much time and money. In Japan, large-scale dams were initially constructed mainly to supply electric power, but the purpose of dams has now shifted to water supply or flood defense. Whether large-scale dams are necessary is now a source of contention throughout the world, with several advanced nations calling for the removal of dams. The present paper, taking as an example a small-scale reservoir for flood control in a small river in Funabashi City, Japan, makes the following main conclusions: small-scale reservoirs were used as a measure of flood control in many parts of Japan in the past; terraced paddy fields as well as small-scale reservoirs play an active role in flood control measures in place of large dams; flood control measures are reinforced by connecting small-scale reservoirs; small-scale reservoirs spare the environment from destruction caused by the construction of large dams; and small-scale reservoirs can be utilized as recreation sites for fishing, swimming, and walking.

Keywords: flood control, small-scale reservoir, dam, electric power, paddy fields.
\end{abstract}

\section{Introduction}

In the $21^{\text {st }}$ century, many nations around the world have begun to take proactive stances with respect to environmental problems. The 2009 United Nations 
Climate Change Conference, Copenhagen Summit, was held at the Bella Center in Copenhagen, Denmark, between 7 December and 18 December, 2009. The conference included the $15^{\text {th }}$ Conference of the Parties (COP15) to the United Nations Framework Convention on Climate Change and the $5^{\text {th }}$ Meeting of the Parties (COP/MOP5) to the Kyoto Protocol. One goal of the conference was to establish a framework for climate change mitigation beyond 2012. The Copenhagen Accord recognizes the scientific case for keeping rises in temperature within $2{ }^{\circ} \mathrm{C}$, but does not contain commitments for reduced emissions that would be necessary to achieve that aim. One part of the agreement pledges USD $\$ 30$ billion to the developing world over the next three years, rising to USD $\$ 100$ billion per year by 2020 , to help poor countries adapt to climate change [1].

Global warming accelerates the normal cycle of rainfall and evaporation, destroying the balance between water supply and demand and having adverse impacts on sea levels, agriculture, human health, animals, plants, and cities, and leading to frequent floods or constant drought and water shortages [2]. Dams are important because they impound water, making it available for drinking, irrigation, electricity production, and industrial use. Dams also control floods and protect farmland. However, a number of problems related to the construction of dams have recently been pointed out. (1) Villages are frequently submerged and many villagers have been forced to leave their homes due to dam construction. (2) In addition, environments have been destroyed, including the loss of forests and animals, the deterioration of river water quality, and decreased aquatic biodiversity. (3) Moreover, dam construction takes a considerable amount of time and money. (4) Finally, there is a considerable amount of danger involved in building a dam.

About 3,200 dams and weirs have been built in Japan. It is now time for us to ask, "Are dams really necessary?" Most of us have noticed that deciduous forests act as "green dams". Due to severe flood damage from heavy rainfall, the Water Resource Development Issue Network Japan suggested in 2004 that (1) dams are not only useless but bring about serious disasters once heavy rain exceeds predicted levels; (2) these disasters are the result of a social structure that depends too heavily on dams and postpones appropriate river planning; (3) devastation of forests lowers dams' water-holding capacity and increases flood damage from driftwood; and (4) structurally defective dikes cause the destruction of embankments and bring about enormous damage. Therefore, the following items were recommended as a means of river management: (1) forest management should be promoted as public works; (2) river planning should be carried out without considering dams as premises; (3) all dikes should be inspected and defective parts should be reinforced immediately; (4) the enormous budget for dam construction should be diverted to river improvement and forest management; and (5) the public must be the main actor in decisionmaking on flood control measures in accordance with regional character [3]. Along with administrative changes, dam removal is also being undertaken in many countries. Flood control measures to replace dams are discussed in the present paper. 


\section{Impact and economics of reservoirs and dams}

There are currently about 210,000 reservoirs and 3,200 dams in Japan. Reservoirs are artificial lakes that store water and then supply that water to fields at the time it is needed. Therefore, the role of reservoirs is to regulate a variable water supply over all seasons and to allow the balanced cultivation of agricultural products. Reservoirs can be used in a number of ways to control the flow of water through downstream waterways. Water in an irrigation reservoir is released into networks of canals mainly for use in farmlands or secondary water systems. Flood control reservoirs, commonly known as attenuation or balancing reservoirs, are used to prevent flooding to lower-lying land; they collect water at times of un-seasonally high rainfall, then release it slowly over the course of the following weeks or months. Some of these reservoirs are constructed across the river line with the onward flow controlled by an orifice plate. When river flow exceeds the capacity of the orifice plate, water builds behind the dam, but as soon as the flow rate decreases, the water behind the dam is slowly released until the reservoir is empty again. In some cases, these reservoirs function only a few times in a decade and the land behind the reservoir may be developed as community or recreational land [4].

The impact of a dam is assessed in several ways: the benefits to human society in terms of agriculture, water supply, damage prevention and power generation; harm or benefits to nature and wildlife; impact on the geology of an area; and the disruption to human lives due to relocation or the loss of archeological or cultural artifacts underwater. Dams affect many ecological aspects of rivers. Older dams often lack a fish ladder, preventing fish from moving upstream to their natural breeding grounds and causing the failure of breeding cycles or blocking migration paths. Even the presence of a fish ladder does not always prevent a reduction in the number of fish reaching upstream spawning grounds. In addition, depending on the circumstances, a dam can either increase or decrease the net production of greenhouse gases. When the reservoir is relatively large and no prior forest clearing has been undertaken in the flooded area, greenhouse gas emissions from the reservoir could be higher than those of a conventional oil-fired thermal generation plant.

The construction of dams has caused over a million people to lose their homes, has brought about the loss of many valuable archaeological and cultural sites, and has resulted in significant ecological change [5]. Japan has a long history of dam construction, maintenance and improvement; however, more than $90 \%$ of the total capacity in Japan has been built since 1950 . High- and largecapacity dams have been constructed in this period supported by economical and technological development. Various dam projects are currently underway in Japan. Electric companies construct dams for power generation, while the Ministry of Agriculture, Fishery and Forestry constructs dams for irrigation purposes. The Ministry of Land, Infrastructure and Transportation (MLIT) and prefecture governments construct dams for multiple purposes, including flood control, because these governments are responsible for river management [6]. 


\section{Case study of a flood control reservoir}

Japan has many small rivers, and a number of urban districts are expanding into the upstream drainage basins or river mouths of small rivers. Funabashi City is located in the northwestern part of Chiba Prefecture, near the downtown area of Tokyo, as shown in Figure 1. Figure 2 shows the river basins of the Funabashi area [7]. Due to its geographical proximity to Tokyo, Funabashi quickly developed into a modern city since 1965 and its population has increased from approximately 43,000 people at the time of the municipal organization in 1950 to approximately 600,000 people in 2010. The Funabashi City area has five drainage basins (Figure 2): (1) the Kanzaki River basin flows to the Tone River through Inba Marsh; (2) the Kannou River basin also flows to the Tone River through the Inba Marsh; (3) the Ebi River basin flows to Tokyo Bay; (4) the Mama River basin flows to Tokyo Bay from Ichikawa City adjoining the west side; and (5) the other river basins flow to Tokyo Bay directly, and to Tokyo Bay through Narashino City adjoining the east side. The Kanzaki River basin covers about $15 \%$ of the area of Funabashi City and has abundant fields; it also contains a large forest and a garbage factory. The Kannou River basin covers about $20 \%$ of the area of Funabashi City. An urban area of apartment buildings spreads over the upper reaches of the Kannou River, but some fields remain in the downstream reaches. There is a park and an arena in this basin. The Ebi River basin covers about $32 \%$ of the area of Funabashi City and has many rivers. The basin contains an athletic field and a wholesale market. The Mama River basin covers about $8 \%$ of the area of Funabashi City and most rainwater flows into Tokyo Bay through the adjoining land of Ichikawa City. There is a park in the Mama River basin. The other river basin covers about $25 \%$ of the area of Funabashi City. A part of this basin fronts onto Tokyo Bay and another part flows into Tokyo Bay through adjoining land of Narashino City. There is a city area and an industrial zone in the other river basin. Most of the other river basin is a public drainage area, and there is a city hall and a public racetrack. Figure 3 shows the Kido River basin with the Misaki River branch.

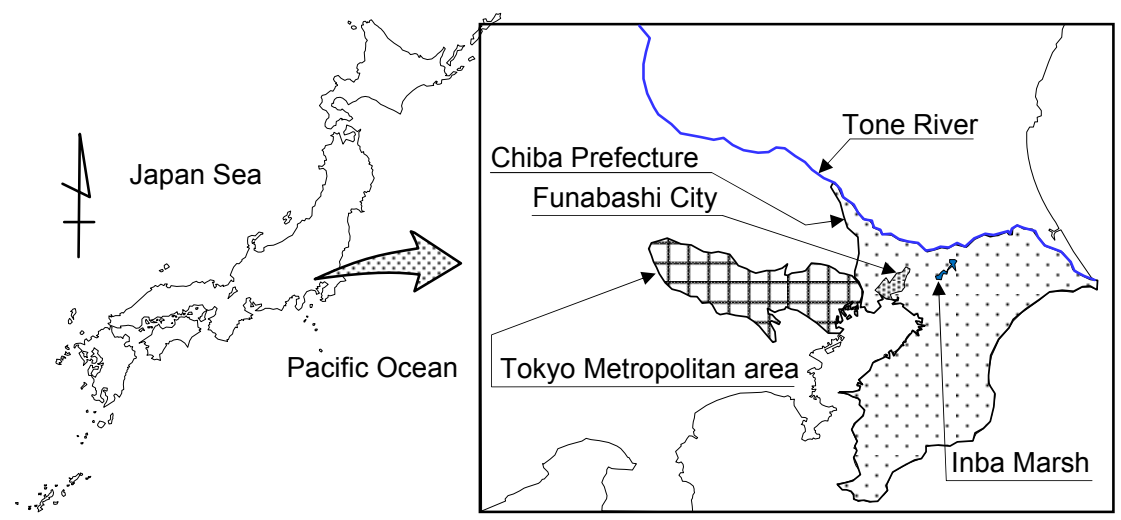

Figure 1: Location of Funabashi city. 
Symbol

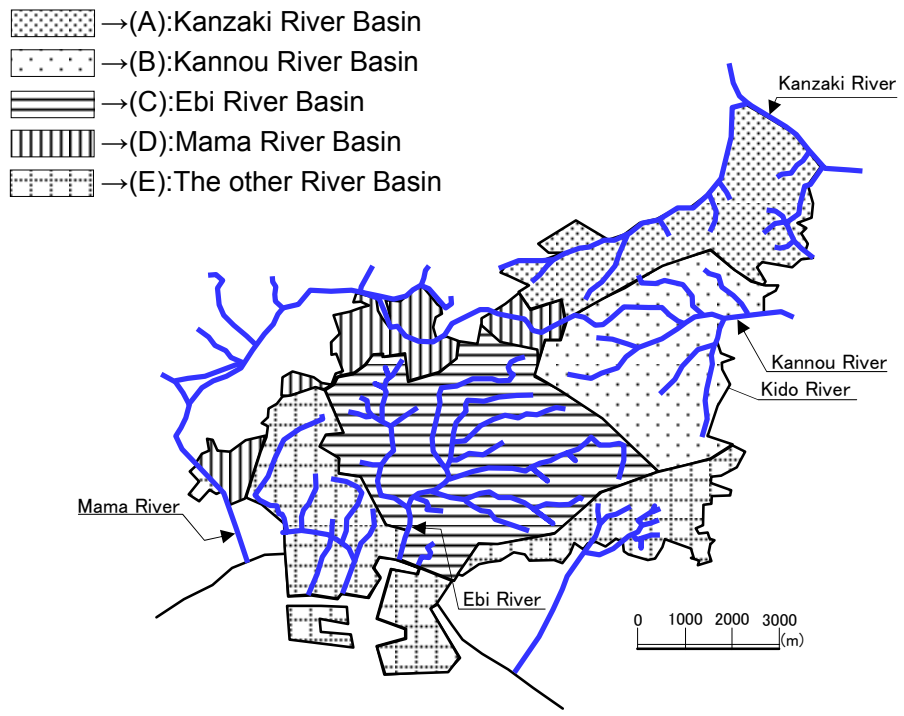

Figure 2: $\quad$ River basins in Funabashi area.

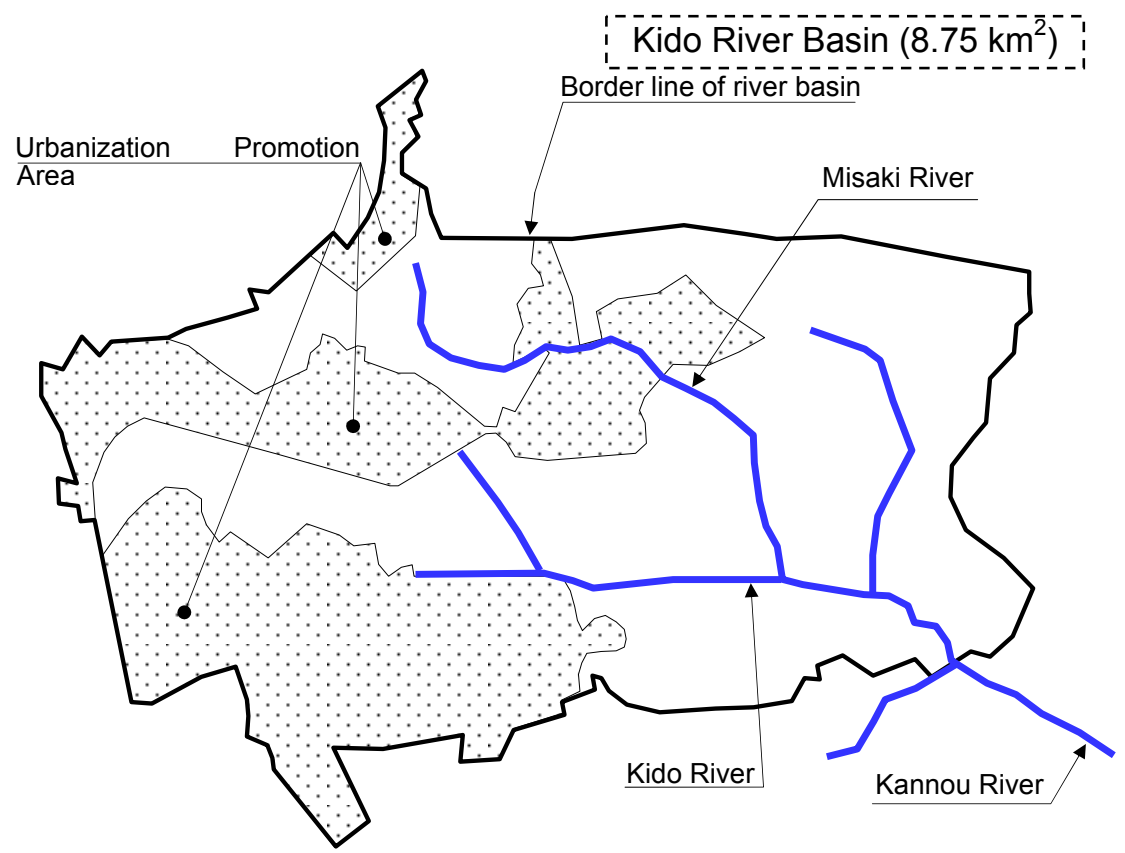

Figure 3: Kido river basin. 
Funabashi City has undergone rapid urbanization since 1960. Therefore, the ability of fields to preserve and store water has been lost, and flood damage has increased remarkably due to an increase of outflow. Flood hazards have increased in all districts, except areas where sewerage facilities have been completed. Even in controlled areas, where there are large-scale fields and significant natural water-saving capacity, the prevention of flood hazard based on river improvement has been not able to keep up with the development of residential and urbanized districts.

The peak discharge $Q_{p}\left(\mathrm{~m}^{3} / \mathrm{s}\right)$ for the rainfall intensity $r=25 \mathrm{~mm} / \mathrm{h}, 50 \mathrm{~mm} / \mathrm{h}$ and $75 \mathrm{~mm} / \mathrm{h}$ were calculated by the rational formula

$$
Q_{p}=\frac{1}{3.6} \mathrm{fr} A,
$$

where $f$ is the discharge coefficient, $r$ is the rainfall intensity $(\mathrm{mm} / \mathrm{h})$, and $A$ is the drainage area $\left(\mathrm{km}^{2}\right)$. For the determination of the channel section, the average velocity of flow $V(\mathrm{~m} / \mathrm{s})$ is calculated by Manning's equation

$$
V=\frac{Q}{F}=\frac{1}{n} R^{\frac{2}{3}} i^{\frac{1}{2}},
$$

where $Q$ is discharge $\left(\mathrm{m}^{3} / \mathrm{s}\right), F$ is sectional area $\left(\mathrm{m}^{2}\right), n$ is coefficient of roughness, $R$ is hydraulic mean depth $(\mathrm{m})$, and $i$ is bed slope. The example of the Misaki district in the Kanno River basin is shown in Table 1, where the peak discharge $Q_{p}\left(\mathrm{~m}^{3} / \mathrm{s}\right)$ is given by the rainfall intensity $r=75 \mathrm{~mm} / \mathrm{h}$ and the volume of sewage $Q_{t}\left(\mathrm{~m}^{3} / \mathrm{s}\right)$ is obtained by $0.001141 \mathrm{~m}^{3} / \mathrm{sec} / \mathrm{ha}$. River basin 1 is the source of the Misaki River, where drains and ditches are constructed on the outskirts of houses and stores. There is no large damage at present in river basin 1. The discharge of river basin 2 flows in concrete double sheet-pile-wall type ditches $(0.6 \mathrm{~m}$ wide and $0.6 \mathrm{~m}$ deep) constructed between houses. The river overflows at rainfall intensity $10 \mathrm{~mm} / \mathrm{h}$ in river basin 2 . River basin 3 flows in fields and overflows at rainfall intensity $25 \mathrm{~mm} / \mathrm{h}$ through the river meanders. The concrete double sheet-pile-wall type ditches $(0.9 \mathrm{~m}$ wide and $0.9 \mathrm{~m}$ deep) are frequently broken by overflow.

Centrifugal reinforced concrete pipes (900 $\mathrm{mm}$ in diameter) are set up in river basin 4 and filled to capacity at rainfall intensity $50 \mathrm{~mm} / \mathrm{h}$. There is a small reservoir with a capacity of $169 \mathrm{~m}^{3}$ in river basin 4 . The river of river basin 5 is built up by concrete double sheet-pile-wall type ditches $(1.20 \mathrm{~m}$ wide and $1.00 \mathrm{~m}$ deep) and the riverbed is muddy and natural. It is difficult to secure the discharge due to a rough riverbed and a fast inflow on uneven land in river basin 5 . River basins $6,7,8$ and 9 are residential lands. Concrete double sheet-pile-wall type ditches (2.00 $\mathrm{m}$ wide and $2.00 \mathrm{~m}$ deep) are set up in river basin 6 and the riverbed has been replaced with concrete. There is little overflow because a large residential land served by the administrative office is developed in river basin 6 . The river confined by concrete revetments ( $3.00 \mathrm{~m}$ wide and $2.60 \mathrm{~m}$ deep) flows in river basin 7 and the riverbed has been replaced with concrete. There is a reservoir with a capacity of $3494 \mathrm{~m}^{3}$ in river basin 7 . The river of river basin 8 is also confined by concrete revetments $(3.00 \mathrm{~m}$ wide and $2.60 \mathrm{~m}$ deep) and the riverbed has been replaced with concrete. There is also a reservoir with a 
capacity of $3600 \mathrm{~m}^{3}$ in river basin 8 . The river of river basin 9 is a concrete double sheet-pile-wall type ditch $(4.00 \mathrm{~m}$ wide and $2.00 \mathrm{~m}$ deep) and the riverbed has been replaced with concrete. River basins 10 and 11 are mostly paddy fields. The river of river basin 10 is constructed from steel sheet pile $(4.00$ $\mathrm{m}$ wide and $2.00 \mathrm{~m}$ deep) and the riverbed has been replaced with concrete. The river of river basin 11 is also constructed from steel sheet pile (4.00 m wide and $2.00 \mathrm{~m}$ deep) and the riverbed has been replaced by concrete. From Table 1, it is assumed that river basins 6-11 are not affected by flooding because the peak discharge at rainfall intensity $75 \mathrm{~mm} / \mathrm{h}$ is less than the calculated flow of their channels. However, it is necessary to dig wider and deeper double sheet-pilewall type ditches in river basins 2 and 3, increase the pipe diameter in river basin 4 , and increase the flow velocity by smoothing the riverbed in river basin 5 .

Table 1: $\quad$ Discharges of the Misaki district.

\begin{tabular}{|c|c|c|c|c|c|c|}
\hline Basin & $A$ & $f$ & $Q_{p}$ & $Q_{t}$ & $Q_{p, t}$ & $\sum Q_{p, t}$ \\
\hline 1 & 0.201 & 0.9 & 3.769 & 0.023 & 3.792 & 3.792 \\
\hline 2 & 0.038 & 0.8 & 0.663 & 0.004 & 0.638 & 4.429 \\
\hline 3 & 0.058 & 0.8 & 0.967 & 0.007 & 0.973 & 5.403 \\
\hline 4 & 0.107 & 0.6 & 1.338 & 0.004 & 1.341 & 6.744 \\
\hline 5 & 0.093 & 0.8 & 1.550 & 0.011 & 1.561 & 8.305 \\
\hline 6 & 0.071 & 0.6 & 0.888 & 0.003 & 0.890 & 9.195 \\
\hline 7 & 0.406 & 0.8 & 6.800 & 0.047 & 6.847 & 16.041 \\
\hline 8 & 0.245 & 0.9 & 4.594 & 0.028 & 4.622 & 20.663 \\
\hline 9 & 0.307 & 0.8 & 5.117 & 0.035 & 5.152 & 25.815 \\
\hline 10 & 0.440 & 0.6 & 5.500 & 0.016 & 5.516 & 31.330 \\
\hline 11 & 0.066 & 0.7 & 0.963 & 0.002, & 0.965 & 32.295 \\
\hline Basin & $F$ & $n$ & $R$ & $i$ & $V$ & $\sum Q$ \\
\hline 1 & & & & & & \\
\hline 2 & 0.36 & 0.020 & 0.200 & 0.004 & 1.081 & 0.389 \\
\hline 3 & 0.81 & 0.020 & 0.300 & 0.006 & 1.736 & 1.795 \\
\hline 4 & 0.64 & 0.013 & 0.225 & 0.006 & 2.202 & 3.194 \\
\hline 5 & 1.20 & 0.025 & 0.375 & 0.006 & 1.611 & 5.127 \\
\hline 6 & 4.00 & 0.020 & 0.667 & 0.006 & 2.956 & 16.950 \\
\hline 7 & 7.80 & 0.020 & 0.951 & 0.004 & 3.059 & 40.807 \\
\hline 8 & 7.80 & 0.020 & 0.951 & 0.004 & 3.059 & 64.664 \\
\hline 9 & 8.00 & 0.020 & 1.000 & 0.007 & 4.183 & 98.180 \\
\hline 10 & 8.00 & 0.020 & 1.000 & 0.007 & 4.183 & 131.596 \\
\hline 11 & 8.00 & 0.020 & 1.000 & 0.007 & 4.183 & 165.063 \\
\hline & & & & & & \\
\hline
\end{tabular}

The northern district of Funabashi City has recently seen rapid urbanization. Therefore, artificial flood control measures for securing the capacity of water retention and retarding as well as river improvement must be efficiently executed in the river basin of this district. It is also necessary to coordinate with the sewerage plan of the river basin. There are many paddy fields and pear 
plantations in the northern district of Funabashi City. These paddy fields and plantations must be conserved to maintain the water retention of the land. The Mama River Basin located at the western district of Funabashi City has also been rapidly urbanized and the capacity of water retention and retarding has been weakened by urban development in areas formerly occupied by fields and forests. Therefore, a storm-reservoir-penetration facility using the grounds of schools or shopping centers should be set up in addition to existing measures of river improvements, regulating reservoirs and drainage appliances. It is also necessary to guide land use in a manner that preserves water retention and retarding in the river basin. The Ebi River Basin facing Tokyo Bay at the southern district of Funabashi City has also been rapidly urbanized since 1955 . Therefore, serious problems such as flooding, lack of fountains, and water pollution have frequently arisen in the Ebi River Basin. Measures to restore water cycles, such as penetration boxes and trenches for rain water, in addition to small reservoirs, are planned in the Ebi River Basin.

\section{Considerations and conclusions}

Flood prevention measures are an ever-present problem for human societies. Recently, the Congress of Well-informed Persons of the Japanese Government discussed whether to proceed with a dam project, and compared the proposed dam project with flood control projects that did not involve dams [8, 9]. They illustrated 25 proposals of flood control for the dam, such as the restoration of polders, regulation of land use along rivers, and reinforcement of riverbanks. The Tokyo Metropolitan Government has proceeded with the reinforcement of existing reservoirs and the maintenance of wide-area reservoirs as flood control measures against recent increased rainfall. Examples of flood control measures for dams are as follows $[10,11]$ :

(1) Effective use of dams to increase pondage by extending dam height;

(2) Preservation of forests to help rainwater penetrate the ground;

(3) Enclosing residential areas with polders;

(4) Opening parts of open levees to allow river water to overflow;

(5) Using roads as levees;

(6) Creation of flood control basins using paddy fields and playgrounds;

(7) Regulation of land use and development;

(8) Storm-water tanks for houses and apartments;

(9) Storm-water inlets to the basements of houses;

(10) Storm-water infiltration facilities;

(11) Storm-water reservoirs for flood control;

(12) Excavation of rivers, increasing discharge by deepening riverbeds and riverbanks.

Retention reservoirs for dams are the best management practice for the management of storm-water runoff and the prevention of flooding in the future. In particular, retention reservoirs are effective along urban rivers in densely populated regions [12]. In Japan, paddy fields, flooded parcels of arable land used for growing rice and other semi-aquatic crops, also play a role in flood 
control as a form of water conservation storage [13]. Heavy rainfall causes floods and other disasters. Water management and hydroelectric generation have been enhanced by the construction of dams in the $20^{\text {th }}$ century. However, there have been many arguments for and against constructing dams in many countries worldwide because of the need for strict appraisals of the ecological and environmental impact of dams before proceeding with public projects. Reservoirs are effective substitutes for dams; in particular, small reservoirs are a widely used form of infrastructure for the provision of water. Although clusters of reservoirs store significant quantities of water and affect downstream flows, they have rarely been considered as systems, with synergies and tradeoffs resulting from their numbers and their density [14]. In the Tokyo metropolitan area, small-scale regulating reservoirs have been planned and constructed since the end of the $20^{\text {th }}$ century. Funabashi City is now advancing its flood control measures by constructing small-scale reservoirs. Reservoirs have various functions that regenerate the hydrologic cycle in river basins, such as environmental preservation, the production of clean streams, the effective use of water resources, and the reduction of flood hazards. In the future, it will be necessary to balance flood control, water utilization and environmental concerns using small-scale reservoirs along rivers in urbanized areas. Moreover, the installation of infiltration inlets and private sewerage treatment tanks in each home will be desirable for the effective use of water resources and wastewater treatment, as well as flood control measures.

\section{References}

[1] COP15, United Nations Climate Change Conference 2009, http://www.webcast.cop15.dk

[2] The APEC Virtual Center for Environmental Technology Exchange, Information on Environmental Policy and Technology, What Results from Global Warming, http://www.epoc.osaka.jp/apec/eng/earth/globalwarming/dounaru.html

[3] Water Resource Development Issue Network Japan, No Dam Is Necessary for Flood Control, http://www7b.biglobe.ne.jp/-yakkun/suigenrennopezi2/home/suigenrentoha/teigen

[4] Wikipedia, the free encyclopedia, Reservoir, http://en.wikipedia.org/wiki/Reservoir.

[5] Wikipedia, the free encyclopedia, Many arguments for and against constructing dams. http://ja.wikipedia.org/wiki/\%E3\%...

[6] Ministry of Land, Infrastructure, Transport and Tourism, River Improvement Measures Taken by the MLIT, http://www.mlit.go.jp/river/basic-info/english/river.html

[7] FUNABASHI CITY, The river basin of Funabashi City, http://www.city.funabashi.chiba.jp/kasenseibi/gksryuiki.htm

[8] Asahi-newspaper, Editorial: review by citizens, 2010.10.20 
[9] Congress of well-informed persons: Interim report of material on flood measures in future, River Bureau, Ministry of Land, Infrastructure, Transport and Tourism, Japanese Government, 2010.

[10] Construction and communication newspaper, Flooding at a time after a local heavy rain, and reinforcement of flood control by connecting reservoirs in Tokyo Metropolitan Government, 2010.7.8

[11] Asahi newspaper, Images of flood control measures for dams, 2010.7.14

[12] K. Sato, Y. Kaneko, K. Izumi, T. Nakayama and M. Takezawa, The River Goes Underground, Proc. of the International Symposium on Comprehensive Watershed Management, pp.539 546, Beijing, China, 1998

[13] Wikipedia, the free encyclopedia, Paddy field, http://en.wikipedia.org/wiki/Paddy-field

[14] M. Andreini, T. Schuetz and L. Harrington, Planning and Managing Small Reservoirs: A Toolkit, SMALL RESERVOIR PROJECT http://www.smallreservoirs.org/full/toolkit/docs/0_Introduction_MTA.pdf 